\title{
Pragmatic approach to construction and reinvention of cities in developing countries: the case of Brazzaville in the republic of Congo
}

\author{
Nzoussi Hilaire Kevin 1 , Li Jiang Feng 2 \\ School of Public Administration, China University of Geosciences, Wuhan, 430074 PR China \\ Corresponding Author: Email:nzoussik@yahoo.fr; Tel: 008615527247645
}

\begin{abstract}
Urbanization is a very old phenomenon and does not date today. For centuries, the urbanization of cities has been inevitably accelerating. In recent years, more than $50 \%$ of the world's population lives in urban areas. This percentage will increase in the coming years. Urbanization poses many problems in the cities of developing countries that require reinvention and pragmatic constructions to achieve sustainable cities. This is the case of Congo Brazzaville capital policy that is growing disproportionately and disorderly without planning methods or urbanization or even adaptation to receive a large population who moved to town in search of well being. Urbanization is a perplexed area and includes several subissues that are: socio-economic, environmental but also spatial. However, Brazzaville is in a state of total disrepair resulting in a dysfunction of the urban space. Brazzaville has inherited a colonial space with a dual character. The pragmatic reconstruction will certainly provide an adequate response to the problems facing the city of Brazzaville. The purpose of this paper is to provide a framework for the regulation and regeneration of the urban environment. Then, rethinking renaming the city of Brazzaville to ensure a pragmatic reconstruction that will allow the populations to have a radiant living environment.
\end{abstract}

\section{Keywords}

Pragmatic approach, construction and reinvention of large cities, Developing Countries, Congo Brazzaville

\section{Introduction}

\section{Overview}

Urbanization is an area realized by the construction of cities. From ancient cities to cities of the Middle Ages, today we have moved to the cities of the third millennium which are characterized by gigantic constructions, otherwise known as the "high tech" which concretize the architectural revolution of the third millennium. Urban regeneration refers to the physical, economic and social renewal of areas that have been subject to decline (Parkinson, 1989). That is the vision of comprehensive, integrated action that leads to the resolution of urban problems and aims to bring about lasting improvement in the economic, physical, social and environmental conditions of an area which has been modified (Roberts, P. and Sykes, H., 2000). Congolese cities, in this case Brazzaville, suffer from total dysfunction due to uncontrolled urbanization. Thus, it is difficult to achieve sustainable development without going through a pragmatic reconstruction which will be the necessary condition of reinventing the said "town" to give it a dimension of the cities of the third millennium. The concept of sustainable development has become the main repository of public planning policies and planning (Wachter, 2003).Urban development (or redevelopment), with its general mission and its less well defined goal, and urban revitalization (or rehabilitation), which, while suggesting the need for action, does not specify a precise method of approach (Couch, 1990).

Reinventing cities is based on the common vision of modernity based on desired urban change (Missilu, 2015). The process of urban change necessarily involves cycles of growth, decline and regeneration (Berry et al., 1993). This article aims to propose a new pragmatic approach to the reconstruction of cities in order to achieve sustainable cities. This work focuses on how to rebuild new cities that can enter the sphere of cities of the third millennium.

\section{Context}

Population growth in almost all African cities is becoming an inescapable phenomenon. This growth of more than $4 \%$ every year is definitely problematic, compared to the Asian cities where Latin American cities seem to be weak (Moustier and Falla, 2004). Indeed, population growth in recent years has led to an increasing demand for urban infrastructure and structures. This leads to a dysfunction of the Congolese cities and in particular Brazzaville, which is in a very difficult state of governance because of the problem of roads, waste management and the anarchic occupation of space. The city of Brazzaville formerly called "Brazza the green" lost its urban character of attractive and no longer gives hope of living easily. During the growing seas on, the living conditions of the populations are deteriorating more and more with the birth of several erosion sites observed on any urban perimeter. The city is a center of concentration, a node of communication (Lacour, 1999). It is therefore a crossroads of encounters between peoples and civilizations that confront each other culturally.

A city that succeeds in terms of sustainable development is a city whose numerous and diverse objectives of the inhabitants and the companies are reached without the cost being borne by other people or other regions (Miltin, 1994). The city is not ... a simple physical and artificial mechanism of construction. He is involved in the vital processes of people who compose; it is a product of nature, and especially of human nature (Park, Burgess and McKenzie, 1925).

During this millennium, cities have become the main centers of attraction and contribute effectively to the development of countries. In other words, the role of cities is essential in the development of the economy, creativity and technological innovation. But, it is always in the cities where the evils that undermine it are concentrated. This is the case of Brazzaville, political and administrative capital is faced with several evils. The different policies of construction and management 
committed to the proper management of the city have hardly brought about the expected results. This is why a pragmatic approach obliges us to reconstruct the city of Brazzaville, which today has lost its splendor and beauty of yesteryear and which must become a pole of attraction, modernity and innovation.

\section{Make a diagnosis}

Several causes are at the origin of the urban growth of the city of Brazzaville. These causes are both endogenous and exogenous. Endogenous factors are of two types. This is particularly true of rural exodus and demographic dynamics (Vennetier, 1990). The increase in the population of Brazzaville suggests an increase in demand for services and goods (Nzoussi, 2014d). Urban growth is based on the concept of an urban fabric that describes the city and its evolution over time. The establishment of cities and their development has given rise to an abundant legis lation. It allows urban planning at different scales to avoid uncontrolled growth (Valey, 2011). However, in the city of Brazzaville, there is an anarchic occupation of the urban space with no real rule of urbanization (Nzoussi, 2015b).

In the context of the urban environment of the city of Brazzaville, it is important to make a diagnosis and to know mainly the problems facing this city. When a diagnosis is made, it is a matter of detecting in the context of medicine, for example, the ills suffered by a patient who may sometimes be in a critical or even comatose condition. So what is your diagnos is? According to the French dictionary LAROUSSE, the diagnosis is the identification of a disease in the context of the suffering patient; in the framework of a structure, it is the identification of a dysfunction or a difficulty (LAROUSSE, 2011). The diagnosis is thus accompanied by a recommendation or remedy to improve performance.

Like most sub-Saharan African cities, Brazzaville is in a very complex situation due to the lack of urbanization standards, inadequate structures and adequate urban facilities. We are witnessing the slum phenomenon. Today, the phenomenon of urban cans is the product of the absence of planning in urban management (Clos, 2012). The city believes in a disproportionate manner and thus violates the norms of urbanization. Roads are continually deteriorating and the problem of sanitation is becoming increasingly blurry because of the absence of a waste management policy. In fact, waste management is not a priority for most jurisdictions and focuses on education, tax collection, agricultural services, water supply and health services (Onibokun, 2001) .Brazzaville is therefore faced with a multitude of problems that make living conditions unpleasant compared to northern cities where life is very attractive.

Table 1: The urban environment

\begin{tabular}{|l|l|}
\hline Facilities & Current condition \\
\hline Bridges, harbor, railroads & In very small quantity \\
\hline Building & Obsolete and uns afe \\
\hline Electricity in all its forms & Cable in a state of dilapidation and a repetition of electricity \\
\hline Housing & Real housing crisis, therefore insufficient \\
\hline $\begin{array}{l}\text { Street, trees, public parks, parks privates, } \\
\text { gardens spaces, green spaces }\end{array}$ & Real housing crisis, therefore insufficient \\
\hline Roads & Bad (Unpaved, impassable, dirty) \\
\hline Telecommunications & even archaic \\
\hline Pathway, sidewalk & Impracticable \\
\hline Transportation & No safe bus, cars, train, boats \\
\hline Water and sanitation & $\begin{array}{l}\text { Lack of water drainage, lack of waste disposal, extinction of sewerage } \\
\text { ( sanitary sewer, storm sewer) }\end{array}$ \\
\hline
\end{tabular}

This table gives an idea of the urban environment of the city of Brazzaville. By examining this table one realizes that the urban environment of Brazzaville is in a defective state. The few infrastructures date from the colonial period and have gradually deteriorated, despite some efforts provided by the main actors of the urban governance of Brazzaville.

\subsection{A historical account of Brazzaville}

\subsubsection{Colonial period: Brazzaville as a colonial city}

Historic city that owes its name to the French explorer P.S Debrazza, Brazzaville has a very rich colonial history. Despite the destruction that affected it, Brazzaville remains a city of history (Brisset-Guibert, 2007). From the nineteenth century onwards, the colonial powers embarked on the conquest of the world and in particular of Africa in order to carve out the colonies which were to be necessary for the supply of the raw materials for the functioning of their industries. Thus, African cities developed. Within the framework of the city of Brazzaville, its urban growth began from 1903 with the development of adminis trative services (Dorier Apprill et al., 1998). The colonial powers have built cities and institutions to increase their 
trade to the detriment of existing indigenous settlements (Missilu, 2015). This has resulted in the duality of cities. On one hand the colonial city, European seats of the administration and on the other the native city, seat of the popular districts. The need for space for the development of the White City justified any forced displacement of Africans (...) based on the widespread view of the need for segregation of residential areas (Martin, 2006). Thus two districts saw the day Bacongo in 1909 and Poto-poto in 1911. In the thirties, the construction of the CFCO (Railroad Congo Ocean) increased the movement of labor. In 1933, the population of Brazza ville reached about 19,000 inhabitants (Dorier Apprill et al., 1998). When it comes to taking stock of colonization, many assumptions assert that colonization has harmed Africa because; it has disorganized the traditional African society. This is all the more true since culture, languages, religion and traditional African political institutions have been supplanted by those of the West in order to facilitate cooperation. France occupied the territory of the current Congo Brazza ville through Debrazza and have built some cities throughout the territory of which Brazzaville, political and administrative capital, where urban growth has been disorganized since independence in 1960. Thus, the political capital had to have the hand put and manage the other cities as well as the localities and departments or regions.

\subsubsection{The post-colonial period}

Congo Brazzaville was a French colony which obtained its independence on August 15, 1960. After independence, the French presence was noticed. In 1960, France had no reason to restrict independence to its former colonies, especially since it was prepared to help them to pass the difficult course of the first day of independence (Mirlande, 1970). But the Congolese were not ready to manage the post-independence period. Thus, after this period, an anarchic occupation took place in Brazzaville, especially during the period when the Congo adopted the Marxist-Leninist regime where the land belonged to the people. Landowners reappeared selling land without subdivision and urbanization standards. This leads to a real anarchic occupation of the urban perimeter. The populations of the rural areas moved in urban areas not only to the conquest of space but also to look for job. This triggered a new anti-urban movement (Steve Ouma Akoth, 2013). This is due to the fact that urban settlement was not accompanied by an urban planning method. The thrust of urban populations was not planned, nor was it part of a wider economic project (Idem)

\subsubsection{The Brazzaville Physical Environment}

The city a social reality outside the field of nature but existing in a relationship constrained with the environmen $t$ (Ferras and Volle, 1991). The urban environment also refers to (...) Urban management, democratization of management and the role of urban issues in public policy (Sach, 1992). The dramatic increase in the population of the city of Brazzaville poses enormous environmental problems. For several years the city of Brazzaville otherwise known as "Brazza the green" no longer meets the environmental needs of this urban agglomeration despite the surrounding forests. Administrative policies initiated in its management have not produced the expected results. The dustbins, foul odors roads as well as infrastructure are in an advanced state of disrepair. This figure gives an idea of the Brazzaville environment (Fig.1)

\section{Fig. 1: Illustration of Brazzaville sprawl}

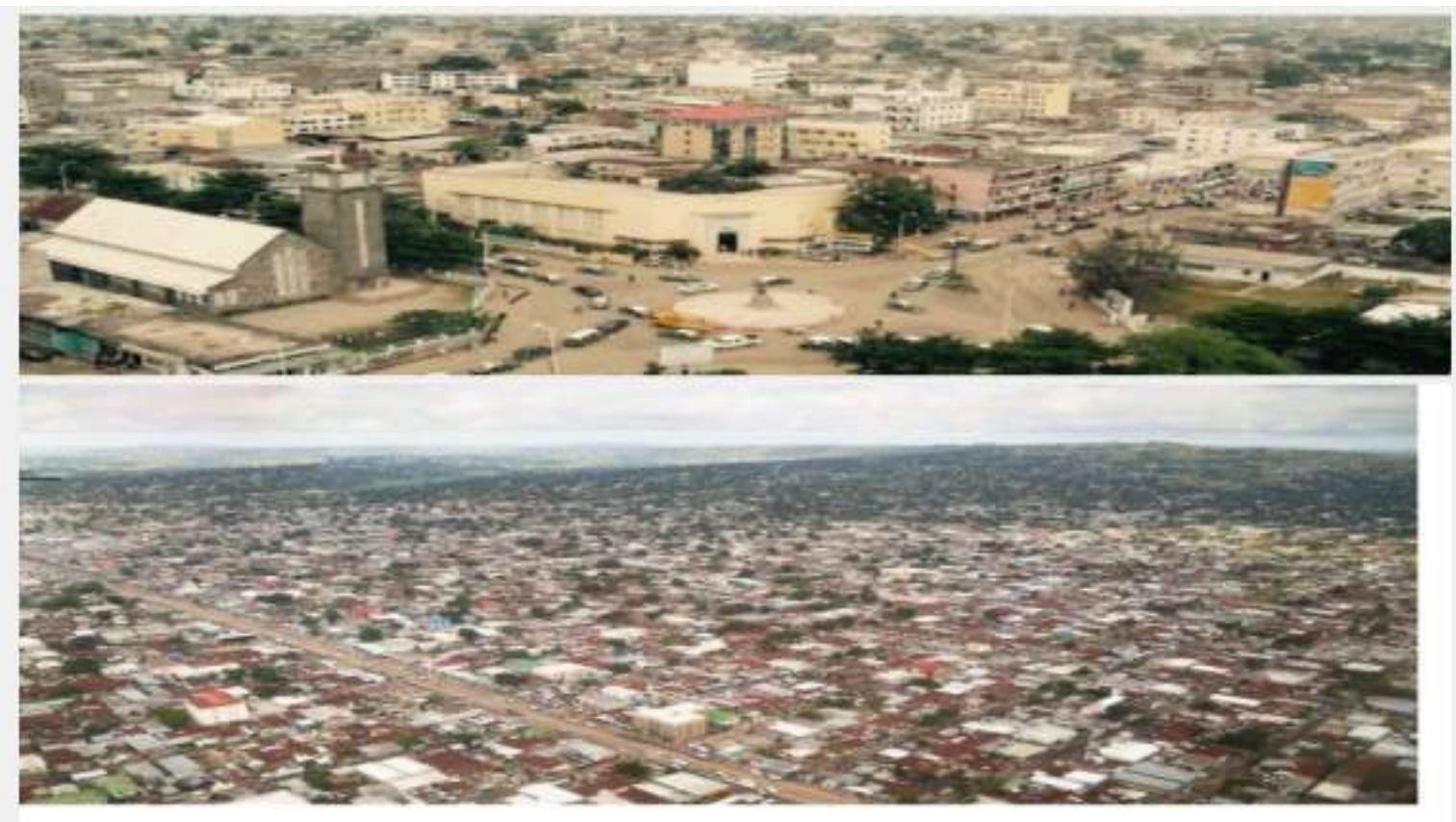

\subsubsection{Description of the study area}

Brazzaville is bordered by the Congo River, it is the political and administrative capital of the Republic of Congo (map of the Republic of Congo, Fig.1), so the seat of power (Fig. 2). 


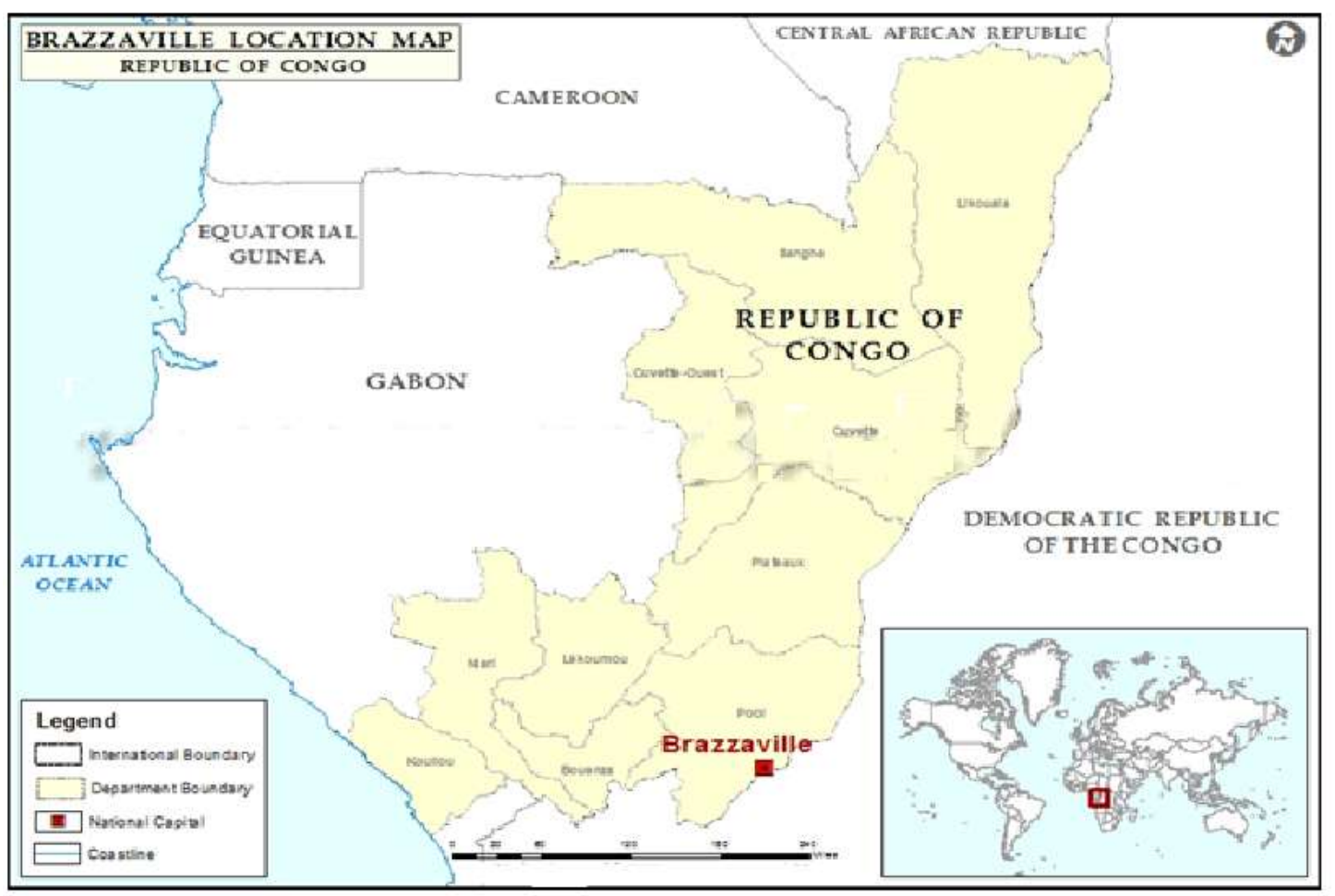

Map of Republic of Congo 


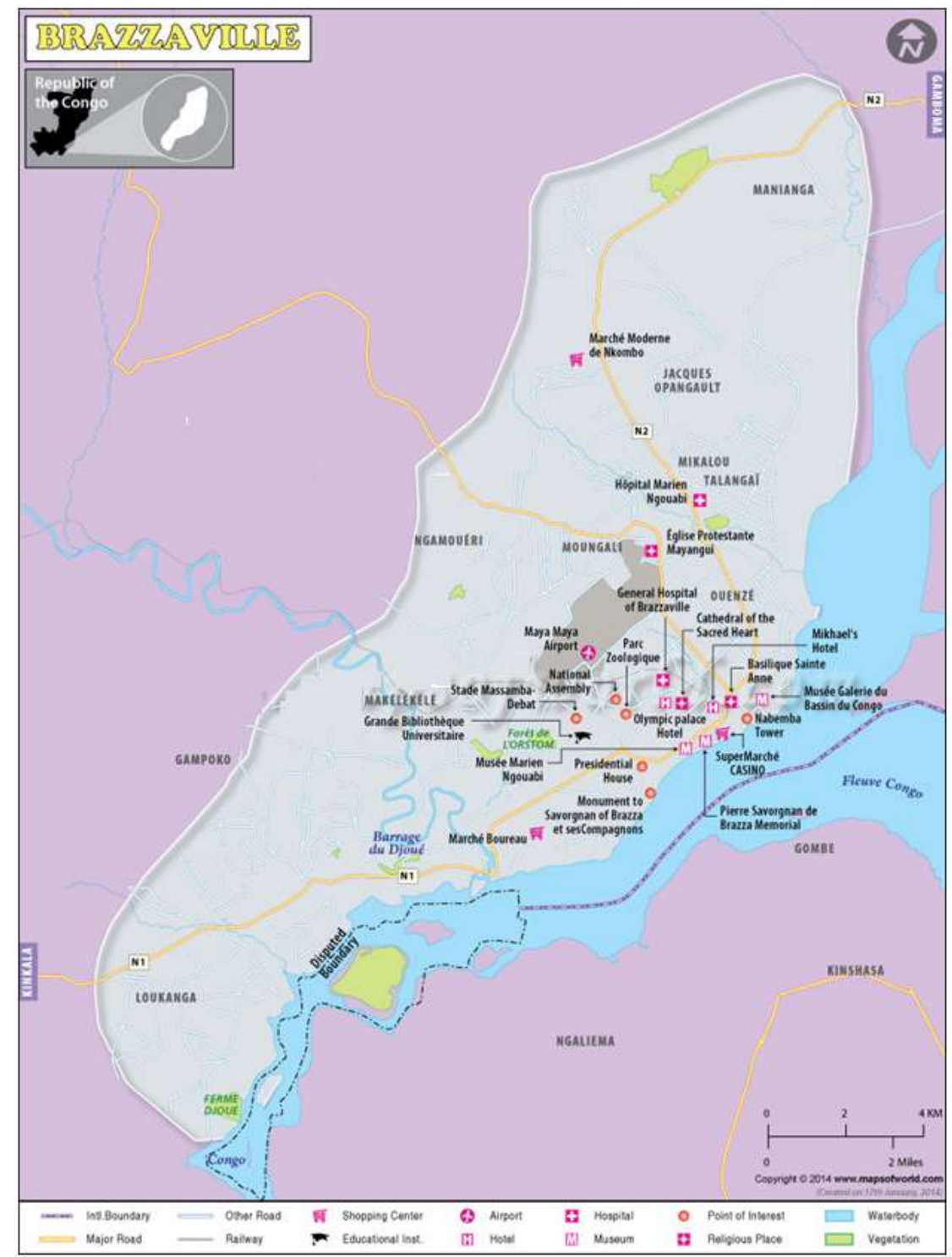

Fig.2 Map of Brazzaville

It is located on the right bank of the Congo River. Brazzaville covered an area of $110 \mathrm{~km} 2$ (Estimate1980) for a population of 1,242,860 inhabitants (2000 Estimates). From this population rose to 1,373,382 inhabitants. Brazzaville lies north of the Congo River. The city is 506 kilometers (314 miles) inland from the Atlantic Ocean and approximately 474 kilometers (295 miles) south of the equator. The city is a commune separated from the other regions of the republic; It is surrounded by the Pool Region. Around the city it's a large savanna. The town is relatively flat, and situated at an altitude of 317 meters (1,040 feet). The city has a geographical area of $263.9 \mathrm{~km} 2$ with a population of 1,373,382 habitants (2007)), gold $5204 \mathrm{hab} / \mathrm{Km} 2$ density.

Indeed, the area of the city of Brazzaville has not been static due to rural-urban migration that accentuates the birth of peripherals areas. Because of the spatial and demographic dynamics, we can even say that the Brazzaville area is growing over the years.

The population of the city of Brazzaville has increased over the years, resulting in a major need for equipment, housing and infrastructure, as the roads constructed by the colonizers have for the most part been degraded. One can thus distinguish two phases of the growth of this population. The first is that which goes from its creation in 1880 until 1960 when the Congo gained its independence. The second phase is from independence to the present. But far from having reliable data from the pre-independence period, we present to you the post-independence data presented in the following manner.

Table 2: Evolution of the population of Brazzaville from 1961 to 2015

\begin{tabular}{|l|l|l|}
\hline Years & Populations & inhabitants \\
\hline 1961 & 122.000 & inhabitants \\
\hline 1974 & 321.000 & inhabitants \\
\hline
\end{tabular}




\begin{tabular}{|l|l|l|}
\hline 1981 & 420.000 & inhabitants \\
\hline 1984 & 590.000 & inhabitants \\
\hline 1990 & 760.000 & inhabitants \\
\hline 1998 & 900.000 & inhabitants \\
\hline 2000 & 1.159 .445 & inhabitants \\
\hline 2005 & 1.242 .000 & inhabitants \\
\hline 2007 & 1.373 .382 & inhabitants \\
\hline 2010 & 1.408 .150 & inhabitants \\
\hline 2015 & 1.700 .000 & inhabitants \\
\hline
\end{tabular}

\section{Source: National Center for Statistics and Economic Studies (NCSEC),}

This table 2 shows the increase of the population of Brazzaville in 1961, that is to say one year after the independence of the Congo at 2015.

The accumulation of the population of Brazzaville has taken place at an exponential rate in view of the above data. In 2000, Brazzaville reached more than 1 million inhabitants. In the aftermath of the fratricidal wars which tore it in the years 1990 to 1999, and after the return of peace, Brazzaville has not ceas ed attracting the neo-city thanks to its multiple functions (political capital of the Congo, University City, Administrative city ...).

Today, out of the 4,500,000 million inhabitants of the country, Brazzaville alone has 1,700,000 inhabitants (Statistics 2015). Its influence is therefore incontestable and constitutes a macro cephalic city.

\subsubsection{The Urban Environment of Brazzaville}

The structuring of cities by modern urbanism (functionalism, zoning, clean slate) is at the origin of dysfunctions which oblige to reconsider the very principles of town planning; The poor quality of the urban environment, the daily environment of three-quarters of Europeans, is a blind spot in urban policies; Conversely, environmental policies focus on natural and rural areas, which are sparsely populated, and urban areas are neglected (Emelianoff, 2007). The continued population growth of large African cities results in remarkable urban sprawl (Arnaud, 1998). The suburbs are still far from the center of cities and lack of basic infras tructure and employment (Dureaud et al, 2000)

The types of habitat, the tenure of the land to be built in Brazzaville and the horizontal construction pose serious problems. (Moutsara, 1986). Estimated to 122,000 inhabitants in $1961,420,000$ in 1981, 900,000 around the years 1998 and 1,373,382 in 2007 (Yekoka, 2008), Today its population is 1700,000 inhabitants (NCSEC, 2015).

\subsubsection{Socio - Economic Environment}

The city plays a vital role as the engine of the economy, place of connectivity, creativity and innovation and service center (European Union, 2011). The city is not only the only chance of obtaining a monetary income but also of access to better conditions of physical well-being: "good eating", "having health", fundamental concems in a potentially rich country, But underdeveloped (Dorier Apprill, 1993). As a city, Brazzaville in reality has to be an attractive city where it is good to live and thus giving multiple jobs to young people and providing them a better living conditions. But the reality is quite the opposite

Unlike the many cities in African countries that attract investors and tourists and businessmen each year, Brazzaville offers rather bitter evidence due to many dysfunctions observed in the city (increasing insecurity, ch ronic unemployment of young people, Lack of electricity ...). The economic environment thus shows a slowdown and many unemployed young people. According to the Doing Business report, a rating agency of the World Bank, published in 2014 in the Congo is 185th out of 189 countries (1). That is to say that the business climate is very detrimental to Congo in general and Brazzaville in particular.

Today with the fall of the oil barrel, the main economic source of the country, there are abusive dismissals especially in the private sector buildings and public works are also affected. While the cities are engines of growth and development poles.

\section{Habitability: habitable city}

To manage and govern a city is to anticipate not being surprised in the future of the mutations that result either from the spatial dynamics or from the growth of the population. In a city, for example, citizen groupings and neighborhoods are not created accidentally, but are determined by several factors (Soubrier, 2000). The growth of the population is always accom panied by multiple consequences, which are very often detrimental.

Indeed, with population growth, urbanization has been based on the densification of existing neighborhoods or on the occupation, on the outskirts of cities, of undeveloped land (...) giving rise to sub-integrated neighborhoods. These are areas where the situation quickly turns to disaster during the rainy box (2). Brazzaville does not give the atmosphere of a habitable city because a habitable city guarantees: decent housing, a well and sanitized environment, quality structures and infrastructures, transport quality ... Essentially a city is the one that ensures and guarantees better conditions and 
quality of life. This common goal leads all responsible agencies and citizens to overcome their differences and coordinate their responses to continuously improve their cities (3). Cities have constantly changed since the beginning of civilization. In response to physical and socio-economic factors, they have increased, decreased or underwent major restructuring (Couch, 1990). This table below is a habitable city model.

Table 3: Table of model of quality of life

\begin{tabular}{|l|l|}
\hline Aspects & People Satisfaction With the City \\
\hline Cultural & $\begin{array}{l}\text { Livable city runs on the principles of equity and justice. It promotes } \\
\text { ethical standards of lifestyle based on interaction of traditional and } \\
\text { modern values. Also; It opens horizons for innovation and skill } \\
\text { acquisition. }\end{array}$ \\
\hline Physical & $\begin{array}{l}\text { (Parks, stadium, gymnasium, museum, museums, museums, } \\
\text { museums, etc.) Art galleries, theaters, fashion houses, green spaces, } \\
\text { etc.). }\end{array}$ \\
\hline Political & $\begin{array}{l}\text { Local governments take effective action to maintain livability; } \\
\text { Decentralization is the pattern of a higher efficiency in governance. }\end{array}$ \\
\hline Environmental & $\begin{array}{l}\text { Protection of natural, built and historic environment; Preserve } \\
\text { ecosystem }\end{array}$ \\
\hline $\begin{array}{l}\text { S livable city promotes social cohesion; It develops supportive services } \\
\text { (transport, education), sanitation, livelihood, sport activates health } \\
\text { services (clean water and medical). } \\
\text { A livable, industrial production, labor markets, trade practices and } \\
\text { financial resources. }\end{array}$ \\
\hline
\end{tabular}

\section{Source: A Systematic approach to reinventing Large Cities in Democratic Republic of Congo: Case} study of Kinshasa the Capital city

This table is an example of a model of life in which the residents of a given city. All items in this table are based on the quality of life of the population of the city of Brazzaville. Thus, all giant cities including the twenty-first century have triggered dynamic political, economic, social and cultural populations and attract environments thanks to their quality of life. Thus, these cities have become major centers of attraction and engines of the global economy, thanks to the activities that take development and meet the well being of the population. But in Brazzaville, the results are far from meeting the needs of the population because of urban that requires governance crisis Major Reforms.

\section{Creative reconstruction as a social innovation}

\subsection{Reconstruction process in urban context}

Historically, men often find adequate solutions to the problems facing them. They put in place all the strategies that are necessary to improve their daily lives. While all public policies are concerned, some are more than others (Epstein, 2013). In the same way as the world evolves, urban architecture evolves and changes considerably. That is why we are talking about the refunding or reconstruction of cities which is a salutary process. Reconstruction serves as a formula for reversing dis ruptive changes. Throughout history, cities have been affected by different phenomena, causing dis ruptive changes that undermine the quality of life (Missilu, 2015). It is difficult to define urban space, the city because of the spatial dynamics (Lefèvre, 1998). Thus the table below shows the situations that have a negative impacton cities.

Table 4: Disruptive Situations in the Reconstruction of a City

\begin{tabular}{|l|l|l|}
\hline \multicolumn{3}{|c|}{ Failure / Collapse of cities } \\
\hline Phenomenon & Problems & Disruptive changes \\
\hline Natural hazards & $\begin{array}{l}\text { Cyclone, drought, storm, } \\
\text { floods, volcano, hurricane, } \\
\text { tsunami, typhoon, } \\
\text { earthquakes, etc. }\end{array}$ & Devastation \\
\cline { 1 - 2 } Urbanization & $\begin{array}{l}\text { Sprawl, overcrowding, open } \\
\text { spaces loss, pollution, } \\
\text { obsoleteness, climate } \\
\text { change, depletion of natural }\end{array}$ & Chaos, decline, decay, \\
\hline
\end{tabular}




\begin{tabular}{|l|l|l|}
\hline War & resources, etc. & $\begin{array}{l}\text { obsoleteness, } \\
\text { environmental } \\
\text { degradation }\end{array}$ \\
& Bombardment, destruction & $\begin{array}{l}\text { Devastation, } \\
\text { Destruction }\end{array}$ \\
\hline
\end{tabular}

This table shows the phenomena that have a negative impact on the reconstruction of a city. Some cities were rebuilt after several events both natural and historical. This is the case of Hiroshima and Nagasaki that suffered nuclear bombing during the 2nd World War. This is also true for Russian and European cities that have suffered German bombing. In 2004, Southeast Asia was damaged by the hurricane, in 2011, the Fukushima disaster also permanently weakened Japan. In 1986, the Chemobyl nuclear disaster in Ukraine also caused significant human and material damage. Brazzaville was also destroyed by the tribal wars of 1993-1999. But all these cities were rebuilt in the summer. Reconstruction is an important policy for rebuilding cities. It allows you to change, enlarge and modify their faces. The interest in these studies of new urban spaces lies in what they reveal about how the various factors underlying change work together (Valérie et al. 2006). Urban regeneration is necessary to bridge the gap between real and desired reality, as it seeks to reverse the vicious spiral in which physical, economic and social problems can be mutually reinforced (Brandon, Lombardi, Bentivegna, 2005).

\subsubsection{Classic Reconstruction: Reconstruction Based on cultural heritage}

It is a model based on the preservation of heritage and cultural heritage. This is very noticeable in European cities which have undergone warfare many modifications after their construction and reconstruction. Here, architecture has not evolved much and serves to conserve archeology, picturesque works and museums.

Clearly, European countries are the true masters of this model, because architecture must preserve the historical and cultural heritage and must serve several generations. This is why we note that these cities are old and that their faces have not changed war for several years. This model, although classic, is now outdated due to the changes linked to the evolution of the world architecture.

\subsubsection{Pragmatic reconstruction}

It is the model based on the practice which is the archetype of the materialization of the high technology with constructions of high standing. It is a process in place to create ultra modem cities meets the requirements of the cities of the 3rd millennium. It is therefore the creation of ultra modern and sophisticated cities based on technological principles. Pragmatic construction thus gives birth to utopian cities. In fact, utopia is the expression of the desire for a better way of being and living (Levitas, 1990).

Indeed, in this urban millennium, many developing countries are transforming their cities, for in the years to come more than half of the world's population will be urbanized. By practicing pragmatic construction, Chinese cities are modemizing and becoming more like North American cities, with Australian and Japanese business centers embodying the CBD (Central Business District). The restructuring of Chinese cities is a local process which operates and provides global processes (Missilu, 2015). It presents an exciting intellectual challenge to the understanding of global processes in different geographical contexts (Laurence JC Ma and Fulong Wu, 2005).

In relation to its pragmatic construction can serve as an example in the reconstruction and modernization of Brazzaville. Chinese cities have become increasingly westernized (Idem) . This has been made possible thanks to the pragmatic construction.

\subsection{The Creative Reconstruction}

People want the right answers, they try to find appropriate solutions to problems, when people want a different way of doing things they adopt innovative approach. The innovation is the introduction or implementation of a new method, practice, policy or service (Van de Ven, 1980).

Indeed, innovation is the introduction of a new idea, the ability to create or invent. The term "innovation" is often used, and the distinction between creativity and innovation is important. (Sternberg and Lubart 1999) defines creativity as "the ability to produce and both new (that is to say original, unexpected) and appropriate (that is to say useful, adaptive). Creativity / innovation is related to the organizational / cultural climate (...) (Burns and Stalker, 1961) .In other words, creativity is the generation of new and useful ideas, mainly to the individual (Amabile et al., 1996).

A country must seek modern says has created innovating. Creative reconstruction is very useful for the reconstruction of the Congolese cities in general and particularly Brazzaville. It is an essential and useful need to regenerate and rebuild Brazzaville to what provides good quality of life to its population. Social innovation is based on experiments to find new solutions to unresolved social problems (Chambon, David and Deverey 1982; Lévesque, 2007). Technical innovation is the result of practices and social experiences (Flichy 1995). Organizational innovation is the creative transgression of establis hed rules (Alter, 2000). The innovation process occurs in an organization (..) (Dosi, 1988).

Clearly, the creative reconstruction brings many positive aspects in the modernization and development of a city. 


\section{3-The concept of sustainable and intelligent city}

A sustainable city is a term that refers to a city or urban unit respecting the principles of sustainable development and the ecological urbanism, which seeks to simultaneously take into account the social, economic, environmental and cultural of the planning for and with locals for example through an architecture (..), facilitating work and modes sober , developing the efficiency point of view of the consumption of energy and natural resources and renewable (4). The smart city is one that can both attract and retain businesses employing highly skilled labor ( 5 ). The latter forms a pole of skills essential for specialization in high-end products to meet competition from low-wage countries (Bouinot, 2004) .The smart city can be easily combined with that of sustainable urban and regional development. The rapid development of new technologies and their uses in urban governance, transport management, accumulated real estate projects and public spaces in a coherent area (European Union, 2011).

Through these definitions we realize that a sustainable city is one that meets the requirements of the cities of the third millennium and provides pleasant living conditions to its population. Thus, we can say that some Western cities are sustainable cities under that definition. But Brazzaville is far from achieving its objectives and is in the forefront of these cities. Therefore, a reconstruction and a more appropriate approach are needed in this city so that it can meet the needs of its growing population.

Brazzaville must: meet the challenges of an integrated and comprehensive manner; matching approaches territories with those focused on individuals or specific groups; combine formal government structures with flexible informal governance structures and tailored to the scale of existing challenges; develop governance systems to bring out shared visions that reconcile divergent objectives and different models of development etc. (European Union, 2011). Thus, it could become a sustainable city and ensure full employment and structures convenient to its population.

\subsection{Urban governance of proximity reinforced as a governance approach of the city of Brazzaville}

Urban governance is strengthened near a new vision that we set up in city governance. In the light of modernity, and especially oblivion by the state to take over the crucial problems of the people especially in the outlying areas of the city of Brazzaville, a wholesome approach is thus proposed, which can be useful to reduce certain problems. So men can significantly improve their quality of life by identifying relevant projects in their districts, community or area. The State will play the role of guide or catalyst. Urban governance is strengthened close to this model that will serve to better identify social problems, develop competent and dynamic structures capable of playing the roles assigned to them (Nzoussi, 2017). The people themselves will be central to any action taken by those in charge of urban governance of the city of Brazzaville.Slum dwellers (...) are described as individuals without agency, their voices are seldom heard (Grant, 2008). The role of the people will be reinforced by systematic monitoring of managements bodies as communities of neighborhoods and residential areas.

John Gardner (1991) says that the decomposition of the community often leads to losing the belief that they can improve the quality of their lives through their own efforts. Despite the differences, the most comprehensive initiatives aimed at promoting the participation of residents and other stakeholders in the problem identification process establish priorities and to set priorities and then design and implement problems (Brown etal, 1996).

People who suffer in urban areas will have the means to find appropriate solutions. Thus urban governance enhanced proximity must be a new model of city governance. People living in poverty must be considered and treated in the rest of society (Goode and Eames 1996).

\section{Conclusion}

This article was intended to propose a new vision in the reconstruction and the creation of new cities in developing countries, particularly in Brazzaville. From the pragmatic building can reinvent African cities and particularly Brazzaville. Brazzaville can be reconstructed through the above approach. In this world, there are more and more urban than rural needs that have cultural and sustainable cities. The city is the place where the economy and ecology clash (Rosnay, 1975) .The nineteenth century urban. The majority of the world population lives in cities: they are now gathered in urban areas of the world, more people than there were people on the entire planet in 1950 (Bochet, 2003).

In this urban millennium, content of urban transformation includes more than urban renewal, because areas th at are not developed before are also part of the urban transformation (Bayram 2006). This is provided that urban reconstruction can give rise to attractive cities, sustainable and intelligent. They are cities that have the ability to attract more people, to ensure their own development and significantly improve the living conditions of populations. The pragmatic approach is a more us eful approach to the reconstruction of the city of Brazzaville.

\section{Acknowledgements}

I would like to say thanks to Professor Li Jiang Feng for his expert and professional supervision. That anyone who has helped me and has notbeen cited, here are the expression mysincere thanks.

\section{References}

1.Alter, N., 2000, Ordinary innovation, Paris, Presses universitaires de France. 
2.Amabile, T. M., Conti, R., Coon, H., Lazenby, J., \& Herron, M., 1996, Assessing the work environment for creativity. Academy of Management Journal, 39(5), 1154-1185.

3.Arnaud M, 1998 Dynamics of urbanization in Africa south of the Sahara, Paris, MAE and ISTE).

4.Becker, Charles, Andrew Hamer, and Andrew Morrison, 1994, Beyond Urban Bias in Africa. London: James Curry

4.Berry,J. \& McGreal,S.,2004, An indicator-based approach to measuring sustainable urban regeneration perfomance: Part I, conceptual foundations and methodological framework, Urb an Studies, 41, pp. 725-755.

5.Bochet B.;DA CUNHA A.,2003, Metropolisation, urban form and sustainable development in CUNHA A.,RUEGG J.(dir),2003, Sustainable development and regional planning, Presses Polytechniques and Univers itaires Romandes,350p

6. BouinotJ., 2004, Smart City, Paris, LG.D. J, 186P

7. Brandon. P., Lombardi. P. L. and Bentivegna, V. (Eds), 2005, Evaluation of the Built Environment for Sustainability, E \& Fnspon, London, 168-179

8. Brisset-Guibert, 2007, Brazzaville, small historical guide, editions 2007,83p

9. Brown, P., and H. Richman, 1993, "Communities and Neighborhoods: How Can Existing Research Inform and Shape Current Urban Change Initiatives?" Background memorandum prepared for the Social Science Research Council's Policy Conference on Persistent Urban Poverty. P-161-176

10. Burns, T., \& Stalker, G. M., 1961, The management of innovation. London: Tavistock. 11.Collins, M. A. \& Amabile, T. M. (1999). Motivation and creativity. In R. J. Sternberg (Ed.), Handbook of creativity (pp. 297-312). Cambridge, UK: Cambridge University Press.

12.Chambon, J.L., A. David and J.M. Deverey (1982), Les innovations sociales, Paris, PUF (Que sais-je ?\# 2014).

13.Clos joans, 2012, Onu-Habitat, Urban Profile of the City of Pointe-Noire, Nairobi, 18p

14. Couch, C. (1990). Urban Renewal Theory and Practice, Macmillan Education LTD, London.

15.Dorier Apprill E,1993, Environment and Health in Brazzaville, from urban ecology to social geography, Paris $X$ University, Doctoral Thesis, $681 \mathrm{p}$

16.Dorier-Apprill E, et al, 1998, living in Brazzaville modernityand crisis every day, Paris, Karthala, 383p

17. Dosi G. 1988 The nature of the innovative process, in Dosi, G., C. Freeman, N., Silverberg, G. and L. Soete, (ed.) Technical change and economic theory, New York, Pinter, pp. 221-238

17.Dureaud et al, 2000, in Metropolis movements, Paris, Anthropos IRD

18.Emelianoff C. "The Sustainable City: The Assumption of an Urban Turning Point in Europe", Geographic Information 2007/3 (Vol. 71), p. 48-65.

19. Epstein R., 2013, The trophies of the urban governance, Local authorities, The French documentation, pp.13-18

20.European Union, 2011, Cities of tomorrow, challenges, visions and perspectives, Brussels, 100p

21.Ferras R. et al, 1991, Environment and Urban Research. Reed, sretie info February; 21-23

22.Flichy, P., 1995 "Technical innovation". Bulletin of the Libraries of France (BBF) n 6, p. 108-

109.<http://bbf.enssib.fr/consulter/bbf-1995-06-0108-007>.

23. Gardner, J.W. 1991.Building Community. Washington, D.C.: Independent Sector.Grantmakers for Children, Youth and Families. 1992. "Vulnerable Children and Families: Philanthropic Perspectives on New Collaborations." Washington, D.C.: Council on Foundations.

24. Goode, J. \& Eames, E. 1996 'An Anthropological Critique of the Culture of Poverty' in Urban Life: Readings in Urban Anthropology (3rd Edition) G. Gmelch and W. Zenner (eds), Waveland Press, Illinois .

25.Grant M. R., 2008, Contemporary Strategy Analysis, Business and economics, Blackwell pub, 482p

26.Grant, R. (2008). A Review of "Planet of Slums, Annals of the Association of American Geographers, 99 (1), $216-219$.

27.Lacour C. et al, 1999, Metropolisation-growth, diversity and fractures, Paris, Economica, 194p.

28. Laurence J.C,Ma and Fulong Wu ,2005, Restructuring the Chinese City, Changing society, economic space, London and New York, Routledge Curzon,285p

29.Lefèvre C., 1998, Metropolitan Government and Governance of Western Countries in Politics and Public Planning, vol.16,n0 2 p54-64

30. Lévesque, Bourque and Forgues ,2001, The new economic sociology. Paris, Desclee of Brouwer

31. Levesque, E. M. and Kewley, L. J. 2007 “The Host Galaxy of GRB 060505: Host ISM Properties”, April, 667, L121 
32.Levitas R.,1990, The concept of utopia, Syracuse University Press ,224p

33.Mirlande H., 1970, The States of the Brazzaville Group in the United Nations, Paris A. Colin,333p

34.Misilu Mia Nsokimieno E. et al,2015,Creative reconstruction :A systematic approach to Reinventing Larges cities in Democratic Republic of Congo, Journal of Sciences Social Research Vol.8 n.1 (elSSN 2321 -1091) p1484-1499

35.Mitlin D. and D. Satterthwaite, 1994, Cities and Sustainable Development, Global Forum 94, Manchester 24-28 June, London, International Institute on Environment and Development, 1

36.Moustier $\mathrm{P}$ et al, 2004, The dynamics of urban agriculture; Characterization and Evolution in OB Smith, Moustier P et al, Sustainability of Urban Agriculture in Francophone Africa.Issues, concepts and Dakar, CIRAD, CDRI methods PP23-29.

37.Nzoussi H. K, 2017, Urban governance and Quality of Life in Brazzaville, PhD Thesis, China University of Geosciences, Wuhan (ongoing PhD Thesis)

38.Nzoussi H.K, Management of the urban environment in Brazzaville; Problems and prospects, European Scientific Journal (ESJ); Vol 10 N0 29 (eISSN1857-7431), p 209-2016, october 2014d

39.Nzoussi H.K,2015 b Urbanization and the risk of flooding in the Congo; Case of the city of Brazzaville ;American Journal of Engineering Research(AJER);Vol.04 .No.1(2320-0847) p48-53

40.Onibokun A.G.et al, 2001, Urban waste management. Solutions for Africa, Paris,

41.Park, Burgess and McKenzie, 1925, The city,University of Chicago Press,239p

42.Parkins on D., 1989, Notification of Workers at High Risk in Annals of the New York Academy ,pp 157-159

43.Roberts, P. et Sykes, H., 2000, Review of: Urban Regeneration in Journal of Urban Design, 6 (2) pp. $234-235$.

44.Rosnay, J. de 1975, The macroscope, towards a global vision, Paris, Seuil, Points, p.52

45 Sachs I., 1992, Urban challenges of the twenty-first century; city, urban and eco-development in another city man sharing

46.Soubier R., 2000, Layouts, Planning and Leisure, Quebec, University Press of quebec,521p

47.Sternberg, R. J., \& Lubart, T. I. (1999). The concept of creativity: Prospects and paradigms. In R. J. Sternberg (Ed.), Handbook of creativity (pp. 3-15). Cambridge, UK: Cambridge University Press.

48.Steve O. A, 2013, http://www.africaresearchinstitute.org/newsite/blog/a-brief-history-of-exclusion-by-steve-oumaakoth/

49. Troin J., 1997, The metropolises of the Mediterranean, Paris, Edisude, 110p

50.Valérie Laurans, «Laurence J. C. Ma and Fulong Wu (eds.), Restructuring the Chinese City : Changing Society, Economy and Space », China Perspectives[Online], 64 | march - april 2006, Online since 21 December 2006, connection on 11 November 2016. URL : http://chinaperspectives.revues.org/615

51.Van de Ven A. et al, 1980, Measuring and Assessing Organizations, Willeyinterscience

52.Vennetier $P$, what cities in tropical Africa? Or problems of rapid urbanization newsletter Geographical Society of Liège, PP63-75, 1990.

53.Wachter S. (dir.) ,2003, Sustainable development:challenges and policies, the Tourd'Aigues, Editions of l'Aube.

54.Yekoka F, Urban spatial practices and imbroglio in Brazzaville, analysis of public administration dysfunction of space Condersia, 2008.

\section{Websites}

1. http://www.afriquinfos.com/2013/10/30/congo-185eme-dans-classement-doing-business-2014-235153.php

2. http://fr .africatime.com/external?url=http://www.jeuneafrique.com/mag/354129/economie/afrique-centrale-metropolesfriche

3. Europe Environment Agency, EEA (2009). Ensuring quality of life in Europe's cities and towns. Tackling the environmental challenges driven by European and global change. EEA Report No 5/2009. ISSN 1725-9177.

4.https://fr.wikipedia.org/wiki/Ville_durable

5.https://fr.wikipedia.org/wiki/Ville_intelligente 